\title{
SPATIAL VARIABILITY OF PRECOMPRESSION STRESS AND VOLUMETRIC WATER CONTENT OF A RED-YELLOW LATOSOL (OXISOL)
}

\author{
VARIABILIDADE ESPACIAL DA PRESSÃO DE PRECONSOLIDAÇÃO E DA \\ UMIDADE VOLUMÉTRICA DE UM LATOSSOLO VERMELHO AMARELO
}

\section{Karina Marie KAMIMURA ${ }^{1}$; Moacir de Souza DIAS JÚNIOR ${ }^{2}$; Marcelo Silva de OLIVEIRA ${ }^{2}$; Gérson Rodrigues dos SANTOS ${ }^{3}$; Paulo Tácito Gontijo GUIMARÃES ${ }^{4}$; Ayodele Ebenezer AJAYI}

1. Universidade Federal de Mato Grosso do Sul, Campus de Chapadão do Sul (UFMS/CPCS), Chapadão do Sul, MS, Brasil; 2. Universidade Federal de Lavras, Lavras, MG, Brasil; 3. Universidade Federal de Viçosa, Viçosa, MG, Brasil; 4. Centro Tecnológico do Sul de Minas, Empresa de Pesquisa Agropecuária de Minas Gerais (CTSM/EPAMIG), Lavras, MG, Brasil; 5 Federal University of Technology, Akure, Ondo State, Nigeria.

\begin{abstract}
The intensive agricultural machinery traffic to which soils under coffee crops are exposed may cause significant changes in soil structure. The goals of this study were to: a) characterize the spatial variability of precompression stress $(\sigma p)$ and volumetric water content $(\theta)$ of a Red-Yellow Latosol (Oxisol) and determine their spatially dependent structures using ordinary kriging semivariograms; b) using this date to construct a load-bearing capacity (LBC) map for the site, identifying the depth with higher ; and c) use the map as a decision support tool regarding agricultural machinery logistic management in coffee plantations. The research was conducted on an experimental farm of the Agricultural Research Company of Minas Gerais (Epamig), Patrocinio, MG, on a clayey Oxisol. Samples were collected from $2.0 \times 1.5 \mathrm{~m}$ sampling pits at intersections of a rectangular $40 \times 150 \mathrm{~m}$ grid, totaling 28 sampling points. The soil samples were collected with metal rings $(0.0254 \mathrm{~m}$ in height and $0.0630 \mathrm{~m}$ in diameter) using an Uhland sampler. Sampling at each pit was at 3 layers: $0.00-0.03 \mathrm{~m}, 0.10-0.13 \mathrm{~m}$, and $0.25-0.28 \mathrm{~m}$, and seven samples arranged in a matrix form were collected at each layer, totaling 588 samples. The $\sigma p$ and $\theta$ showed a spatially dependent structure. The depth of 0.00-0.03 m showed higher LBC, indicating that this depth was more compacted compared to other depths. Based on the $\sigma p$ maps, the tractor and the combine should not traffic into the areas at water content of $0.45 \mathrm{~m}^{3} \mathrm{~m}^{-3}$, because the soil has a LBC of $200 \mathrm{kPa}$. If this condition is not respected, additional compaction will occur. Tractor traffic is permissible when the water content reaches values less than $0.36 \mathrm{~m}^{3} \mathrm{~m}^{-3}$, whereas for combine traffic, the water content values must be less than $0.30 \mathrm{~m}^{3} \mathrm{~m}^{-3}$.
\end{abstract}

KEYWORDS: Compaction. Geostatistics. Load-bearing capacity.

\section{INTRODUCTION}

The application of modern farming and harvesting techniques in coffee culture has increased vulnerability to land degradation and this poses a serious challenge to long-term productivity of the farms. Some mechanical properties of the soil are altered and the dynamic balance of this natural resource is affected (GONTIJO et al., 2011). Moreover, the use of heavier agricultural machinery in most of the production stages without adequate control of applied pressure, vis-a-vis soil moisture, is known to promote the degradation of soil structure and could reduce crop yield (ARAÚJO JÚNIOR et al., 2011).

To prevent the negative consequences of these improved farming methods, a foreknowledge of the internal strength properties and load-bearing capacity of the soil is essential. One widely agreed on parameter, which characterizes the mechanical strength of the soil, is the precompression stress (AJAYI et al., 2009). Precompression stress, defines internal soil strength of soils and effectively depicts the maximum pressure the soil had been subjected to in the past (HORN and FLEIGE, 2003). The precompression stress $(\sigma p)$ is derived from the compression curve, which is a plot of the changes in soil bulk density or void ratio against the logarithm of the applied pressure to the soil. The application of pressure lower than the $\sigma p$ to the soil causes an elastic (recoverable) deformation, but when the pressure applied to the soil is higher than the $\sigma p$, irrecoverable plastic deformation of the soil structure occurs (SILVA et al., 2016). Consequently, $\sigma p$ has been used by several authors as an indicator of sustainability of soil structure 
under varying load-bearing conditions (GONTIJO et al., 2011).

When the precompression stress of the same soil is determined at different water content, it can be used to generate the load-bearing capacity characteristics of the soil (AJAYI et al., 2009). In general, when the soil is dry, it has greater loadbearing capability and compaction susceptibility is reduced. However, wetter soil has a lower loadbearing capacity and is more vulnerable to compaction when subjected to traffic (NEIVA JÚNIOR et al., 2015). Therefore, the determination of the precompression stress as a function of soil moisture would aid in decision making regarding the timing of mechanized operations on the farm (KONDO, 2003). Moreover, knowledge of the spatial variability of precompression stress is necessary for traffic management.

In Brazil, the spatial variability of precompression stress in coffee plantations was studied by Gontijo et al. (2011). The author developed a load-bearing capacity distribution map, which forms the basis for a trafficability map for the coffee plantation. Spatial characterization of soil attributes in agriculture requires the use of geostatistical methods, which is the application of the theory of stochastic processes in the estimation of the structure of phenomena linked with spatial coordinates. When a phenomenon displays a certain spatial structure, it is said to be regionalized. If $Z(x)$ indicates the value at the point of spatial coordinates $\mathrm{x}$ and $\mathrm{z}$ is a variable that characterizes this phenomenon, it is said that $\mathrm{Z}(\mathrm{x})$ is a regionalized variable (MATHERON, 1971). According to Cambardella et al. (1994), the variability of soil physical properties can be intrinsic or extrinsic. Intrinsic variability has a strong spatial dependence caused by natural changes on the ground, notably those of pedogenetic origin, such as parent material, mineral weathering, and accumulation of organic matter, among others. The extrinsic variability has lower spatial dependence and is caused by changes in land use, such as cultural practices, plant species, erosion, and compaction, among others.

The use of geostatistics in the study of spatial variability of soil physical and mechanical attributes allows for the identification of the spatial dependence of the data structure. This enables the development of a distribution map of these attributes in the field by using the kriging technique, which interpolates an unbiased estimator with minimum variance (JOURNEL; HUIJBREGTS, 1991) of the semivariogram. According to Vieira et al. (2010), the quality of geostatistical calculations depends on the estimated model (adjusted) of the semivariogram. Thus, it is critical to have a qualitative representation of the data within the semivariogram (greater range) to have quality kriging (the maps).

The objectives of this study were to: (a) characterize the spatial variability of precompression stress $(\sigma p)$ as a function of volumetric water content $(\theta)$ on a Yellow Red Latosol (LVA); b) develop representative maps and using these maps to identify layers with higher loadbearing capability within the farm, and c) propose a decision support system on year-round trafficability for this farm.

\section{MATERIAL AND METHODS}

The study was conducted within the commercial coffee plantation of Empresa de Pesquisa Agropecuária de Minas Gerais (EPAMIG), located in Patrocínio, MG (18 59'31"S, $\left.46^{\circ} 59^{\prime} 31^{\prime \prime} \mathrm{W}, 934 \mathrm{~m}\right)$. The geological complex of the study area, known as Arco da Canastra, separates the sedimentary basins of São Francisco and Paraná. The climate is Aw, according to the Köppen classification, with two distinct seasons, dry winter and rainy summer, with an average annual rainfall of 1,620.1 mm (SILVA; MALVINO, 2005). The predominant vegetation is the Cerrado (savannah) type. The terrain is flat to gently rolling, with an average slope of $3 \%$ and the soil is classified as a Red-Yellow Latosol (Oxisol) according to Embrapa (2018).

The coffee (Coffea arabica L.) crop was established in February 1999 with a spacing of 3.80 $\times 0.70 \mathrm{~m}$ on an area that had been used as a permanent grassland. Preliminary weed control in the farm was by applying pre-emergent herbicide (with oxyfluorfen as the active ingredient). Subsequently, phytosanitary control was conducted once a month, using the spray, ARBUS $2000 \AA$, with a mass of approximately $2,600 \mathrm{~kg}$ when fully loaded. Fertilizer was applied every 40 days, using the fertilizer with a total mass of $600 \mathrm{~kg}$ when fully loaded. In all agricultural operations, the Massey Ferguson tractor model 275, with a mass of 3,900 $\mathrm{kg}$ and power of $45 \mathrm{~kW}(61 \mathrm{hp})$ was used. The rear tires (18.4-30 R1) were inflated to $96.5 \mathrm{kPa}$ and the front tires $(7.50-16 \mathrm{R} 1)$ were inflated to $240 \mathrm{kPa}$. Harvesting was conducted with a Jacto KTR Advance combine with a mass of $6,850 \mathrm{~kg}$, and $10 \times$ 24 tires inflated to $276 \mathrm{kPa}$.

\section{Soil sampling}

The farm was divided into rectangular grids of $150 \times 40 \mathrm{~m}\left(6,000 \mathrm{~m}^{2}\right)$ in October 2010, 
providing 28 sampling points. At each sampling point, undisturbed soil cores were collected in metal rings $(0.0254 \mathrm{~m}$ height and $0.0630 \mathrm{~m}$ diameter $)$ using an Uhland sampler. The samples were collected at $0.00-0.03 \mathrm{~m}, 0.10-0.13 \mathrm{~m}$, and $0.25-$ $0.28 \mathrm{~m}$ from sampling within $2.0 \times 1.5 \mathrm{~m}$ carefully dug pits (Figure 1) to avoid self-compaction. At each depth, seven samples were collected, totaling 21 samples per sampling pit (point) and 588 samples from the plantation. The samples were covered with plastic film and paraffin to preserve soil structure until analysis to determine its physical and hydraulic characteristics.

\section{Determination of precompression stress and water retention}

To determine precompression stress after field sampling, the samples were initially saturated by capillary rise and thereafter equilibrated to a matric potential of $-6 \mathrm{kPa}$ on ceramic plates placed within a pressurized chamber and weighed. They were then used for a uniaxial compression test in a pneumatic Terraload S-450 consolidometer (Geo Enterprises, Durham, USA), as described by Dias Júnior (1995). Each sample, kept within the compression cell, was pneumatically stressed (normal stress) at 25, 50, 100, 200, 400, 800, and $1,600 \mathrm{kPa}$ in steps. Each pressure step was applied until $90 \%$ maximum deformation was reached as described by Taylor (1948), and then increased to the next step, without stress relief between steps. The change in the bulk density of the sample because of the applied stress was monitored through a digital readout fitted with a transducer. After the test, the samples were dried in an oven at $105^{\circ} \mathrm{C}$ for $48 \mathrm{~h}$ for the determination of bulk density, according to Donagema et al. (2017). The volumetric water content $(\theta)$ of each sample was calculated by the equation 1 :

$\theta=(\mathrm{U} \times \mathrm{Ds})$

The soil compression curve was obtained by graphically adjusting, for each sample, the log of the applied pressure (base 10) on the abscissa using the bulk density as the ordinate axis. The precompression stress value for each sample was determined from the stress strain curves (final value for each loading step vs. log normal stress) using Dias Junior and Pierce (1995) method.

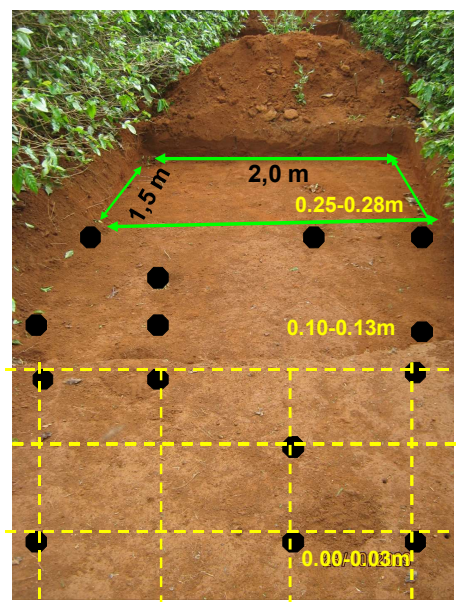

Figure 1. Sampling pit with three steps corresponding to the layers $0.00-0.03 \mathrm{~m}, 0.10-0.13 \mathrm{~m}$, and $0.25-0.28$ $\mathrm{m}$

\section{Statistical and geostatistical analyses}

Basic (descriptive) statistical analyses of the data were conducted with the statistical program Sisvar (FERREIRA, 2011). The measures of location (mean, median, mode, minimum, maximum), dispersion (range, standard deviation, variance, coefficient of variation), and distribution (skewness and kurtosis), as well as the Shapiro-Wilk normality test were conducted. Thereby, the normality of the dataset was investigated according to Diggle and Ribeiro (2000) because data exhibiting a normal distribution provide better predictions when used in geostatistical analyses. For the analysis of the coefficient, we used the classification criteria of Warrick and Nielsen (1980), which classified low variability as values less than $12 \%$, average as values between 12 and $60 \%$, and high as values greater than $60 \%$. For the analysis of asymmetry, we used the classification presented by Ferreira (2009), which defines a right asymmetric distribution as occurring when a3 $>0$, whereas a left asymmetric distribution was defined as a3 $<0$, and the distribution was symmetric at a $3=$ 0 . For the analysis of kurtosis, which is represented 
in the literature by a 4 and b2, we used the Ferreira classification (2011), where the value of a $4=3$ is mesokurtic and values of a4 $>3$ represent leptokurtic distributions, and a $4<3$ values represent platykurtic distributions.

To perform the geostatistical analyses, we used the $\mathrm{R}$ program and the geoR package developed by Ribeiro Junior and Diggle (2001). For proper spatial analysis data, it is assumed that each sampled point has a different random variable, generating a stochastic process (VIEIRA et al., 2010). The intrinsic stationary condition was used for the analysis, requiring only existence and a stationary semivariogram (VIEIRA et al., 2010). From this hypothesis, we built the experimental semivariogram using the data collected at the 588 sampling points. The semivariance values were estimated by equation 2 :

$$
\hat{\gamma}(h)=\frac{1}{2 N(h)} \sum_{\mathrm{i}=1}^{N(h)}\left[\mathrm{Z}\left(\mathrm{X}_{\mathrm{i}}\right)-Z\left(X_{i}+h\right)\right]^{2}
$$

where $\mathrm{N}$ (h) is the number of pairs of measured values $\mathrm{Z}(\mathrm{X})$ and $\mathrm{Z}(\mathrm{X}+\mathrm{h})$ is separated by a vector $h$ (JOURNEL; HUIJBREGTS, 1991). The chart based on the corresponding values of $h$ is called the semivariogram. The notation $\mathrm{h}$ is a vector function and depends on both the magnitude and direction of $h$. After the calculations of the semivariances, theoretical models of spherical and exponential type using the method of weighted least squares were adjusted. After choosing the semivariogram model, interpolations were conducted using ordinary kriging to predict and map the attribute values under study. The spherical model adjusted by the least squares method to the weighted semivariogram showed an increasing spatial correlation structure with distance to some extent (range), from which the semivariance becomes constant, restricting the sample area of influence. According to Journel and Huijbregts (1991), the exponential model asymptotically reaches a plateau, with the practical effect given three times the theoretical reach. For the analysis of the $\mathrm{Co} /(\mathrm{Co}+\mathrm{C})$, which measures the degree of spatial dependence of soil variables, we used the classification of Cambardella et al. (1994), which states that the variable is considered to be highly dependent when the relationship is $\leq 25 \%$, it is moderately dependent between 25 and $75 \%$, and it is weakly dependent if $>5 \%$.

\section{RESULTS AND DISCUSSION}

\section{Descriptive statistics}

The basic structure of the water content and precompression stress data are presented in Table 1. The results showed that the data are well dispersed. At all the studied layers, the water content showed a low coefficient of variation, whereas the coefficient of variation of the precompression stress was in the average, class according to the criteria of Warrick and Nielsen (1980).

The precompression stress and volumetric soil moisture showed an asymmetric distribution to the right. According to Ferreira (2009), the classical statistical asymmetric distribution to the right occurs when the arithmetic mean value is increased as a result of higher than expected values of some data point; therefore, the central tendency values will be in the order of mean $>$ median $>$ mode. The median can, on some occasions, be more advantageous than the mean because it is not affected by extremes. If the distributions are asymmetrical, the median may be a better measure of central tendency (FERREIRA, 2009). The water content in the 0.10$0.13 \mathrm{~m}$ layer exhibited a platykurtic distribution, according to Ferreira (2009). This indicated that the distribution had inherent variability, whereas the water content in the $0-0.03$ and $0.25-0.28 \mathrm{~m}$ layers and $\sigma p$ in all layers exhibited a leptokurtic distribution with most of the dataset in the distribution concentrated around the mean (homogeneity). The ideal distribution would be mesokurtic, wherein the frequency distribution has a normal distribution.

The water content in the $0.10-0.13 \mathrm{~m}$ and $0.25-0.28 \mathrm{~m}$ layers had the same mean, median, and mode; however, in the $0-0.03 \mathrm{~m}$ layer it was different. The volumetric water content in the 0.10 $0.13 \mathrm{~m}$ layer showed a normal distribution with a $1 \%$ probability according to the Shapiro-Wilk test (Table 1). Although the normality of the dataset was not a critical requirement for geostatistical analysis (VIEIRA et al., 2009), it was helpful to understand the spread of the collected data. The standard deviation, coefficient of variation, maximum, minimum, and range of the dataset provided insights into the magnitude of variability of the physical attributes of the various soil parameters; however, the spatial dependence structure of these attributes was not completely understood until we generated the semivariogram (SEIDEL; OLIVEIRA, 2016) 
Table 1. Descriptive statistics for the precompression stress $(\sigma p)$ and volumetric soil moisture $(\theta)$ at $0-0.03$, $0.10-0.13$, and $0.25-0.28 \mathrm{~m}$ layer.

\begin{tabular}{lllllll}
\hline \multicolumn{1}{c}{ Statistical } & \multicolumn{3}{c}{$\theta\left(\mathrm{m}^{3} \mathrm{~m}^{-3}\right)$} & \multicolumn{3}{c}{$\sigma \mathrm{p}(\mathrm{kPa})$} \\
\cline { 2 - 7 } & \multicolumn{3}{c}{ Payers $(\mathrm{m})$} & & \multicolumn{3}{c}{ Layers $(\mathrm{m})$} \\
\cline { 2 - 7 } $\mathrm{n}$ & $0.0-0.03$ & $0.10-0.13$ & $0.25-0.28$ & $0-0.03$ & $0.10-0.13$ & $0.25-0.28$ \\
Mean & 196 & 196 & 196 & 196 & 196 & 196 \\
Median & 0.44 & 0.44 & 0.43 & 162.40 & 147.20 & 152.33 \\
Mode & 0.44 & 0.44 & 0.43 & 154.49 & 138.80 & 140.72 \\
Variance & 0.46 & 0.44 & 0.43 & 152.12 & 134.76 & 132.72 \\
SDEV & 0.001 & 0.001 & 0.001 & 2654.23 & 2900.82 & 2952.41 \\
$\mathrm{CV}$ & 0.033 & 0.032 & 0.038 & 51.52 & 53.86 & 54.34 \\
Asymmetry & 7.65 & 7.15 & 8.82 & 31.72 & 36.59 & 35.67 \\
Kurtosis & 0.29 & 0.15 & 0.63 & 1.42 & 2.04 & 1.10 \\
Minimum & 3.97 & 2.73 & 6.58 & 6.91 & 10.83 & 5.13 \\
Maximum & 0.35 & 0.37 & 0.31 & 5.83 & 6.53 & 13.86 \\
Amplitude & 0.58 & 0.52 & 0.64 & 366.41 & 417.21 & 373.68 \\
S.W. & 0.23 & 0.15 & 0.33 & 7.00 & 7.62 & 6.62 \\
\hline
\end{tabular}

* significant at $1 \%$ probability according to the S.W.; n, sample size; CV, Coefficient of variation; S.W., the probability value of the Shapiro-Wilk test.

\section{Spatial variability}

The precompression stress and volumetric water content exhibited spatial dependence (Table 2 ). The precompression stress values at the 0.00 0.03 and $0.10-0.13 \mathrm{~m}$ layer fit a spherical model, whereas at the $0.25-0.28 \mathrm{~m}$ layer, an exponential model was the best fit. The representative model for the volumetric water content at the layers was also exponential. Thus, besides the intrinsic stationarity, which can be assumed, the dataset also met the stationary second-order level for the construction of the semivariograms. The analysis provided by the semivariograms is best suited to support inferences about the structure of spatial dependence (YAMAMOTO; LANDIM, 2013).

The precompression stress have a high nugget effect for all layers analyzed, when compared to the volumetric soil moisture content (Table 2). The nugget effect (Co) is a completely random experimental variability and is not spatially structured. Often this effect is not caused by the detection of spatial variability in structure for distances smaller than the smallest distance for the sample used (VIEIRA et al., 2010).

The practical range for the precompression stress in the $0-0.03,0.10-0.13$, and $0.25-0.28 \mathrm{~m}$ layers were $8.33 \mathrm{~m}, 6.71 \mathrm{~m}$, and $7.54 \mathrm{~m}$, respectively (Table 2). For volumetric soil moisture content, the practical range in the $0-0.03,0.10-0.13$, and $0.25-0.28 \mathrm{~m}$ layers were $11.98,14.98$, and $16.48 \mathrm{~m}$, respectively (Table 2 ).

Kondo (2003) studied the spatial variability of precompression stress and gravimetric moisture content in coffee plantations in the $0.00-0.05 \mathrm{~m}$ layer under the line of traffic with the gravimetric moisture content of $0.05,0.15,0.25,035$, and 0.45 $\mathrm{kg} \mathrm{kg}^{-1}$ and obtained the values $2.10,1.81,3.04$, 4.36, and $3.13 \mathrm{~m}$, respectively. Gontijo et al. (2007) obtained range values equal to 19.5 and $90 \mathrm{~m}$ for the $\sigma p$ and $\theta$, for the $0-0.03 \mathrm{~m}$ layer.

Based on the values of spatial dependence suggested by Cambardella et al. (1994), there was moderate spatial dependence for the precompression stress at all layers and water content in the $0-0.03 \mathrm{~m}$ layer. For volumetric moisture content in the 0.10 0.13 and $0.25-0.28 \mathrm{~m}$ layers, this relationship did not apply because the nugget effect in this case was null. 
Table 2. Estimated parameters of the adjusted theoretical model for $\sigma p$ and $\theta$

\begin{tabular}{|c|c|c|c|c|c|c|c|}
\hline Parameter & Layers & Models & Co & $\mathrm{C}$ & $\begin{array}{l}\text { Range } \\
\text { practice }\end{array}$ & $\mathrm{Co}+\mathrm{C}$ & GD \\
\hline \multirow{3}{*}{$\sigma_{p}$} & $0.00-0.03$ & Sphe & 2000 & 677.27 & 8.33 & 2667.23 & 75 \\
\hline & $0.10-0.13$ & Sphe & 1800 & 1276.7 & 6.71 & 2913.86 & 62 \\
\hline & $0.25-0.28$ & Exp & 2273 & 824.21 & 22.60 & 2952.41 & 77 \\
\hline \multirow{3}{*}{$\theta$} & $0.00-0.03$ & Exp & 0.0005 & 0.0006 & 11.98 & 0.0011 & 45 \\
\hline & $0.10-0.13$ & Exp & 0.0000 & 0.0010 & 14.98 & 0.0009 & - \\
\hline & $0.25-0.28$ & Exp & 0.0000 & 0.0016 & 16.48 & 0.0015 & - \\
\hline
\end{tabular}

Co, nugget effect; Co + C, sill; GD, the degree of spatial dependence; Sphe, spherical; Expo, exponential.

\section{Kriging}

Because we were able to generate the representative semivariogram variables and their spatial dependence structure, they could be used to interpolate the values at any point within the coffee plantation, without bias and with minimum variance by ordinary kriging. The resultant kriging maps of the load-bearing capacity and volumetric soil moisture content are presented in Figures 2a-c and 3 a- c.

In Figure 2a, it can be seen that the dominant map regions have a load-bearing capability (LBC) of $200 \mathrm{kPa}$ (in orange), whereas the region with the lower LBC had values below $100 \mathrm{kPa}$ (green). The areas with moderate LBC had values of approximately $150 \mathrm{kPa}$ (yellow). There were some patches with LBC greater than $200 \mathrm{kPa}$, which are represented in a pink hue. On the map in Figure $2 b$, the region that dominated the LBC corresponded to $100 \mathrm{kPa}$ (green) and regions with lower LBC ranged from 100 to $200 \mathrm{kPa}$ (yellow). In Figure 2c, predominant $\mathrm{LBC}$ ranged from 50 and $150 \mathrm{kPa}$ being green and yellow, respectively.

In Figure 3a, the dominant volumetric water content in the $0-0.03 \mathrm{~m}$ soil layer was approximately $0.45 \mathrm{~m}^{3} \mathrm{~m}^{-3}$ (orange). This moisture regime also predominated the $0.10-0.13$ (Figure $3 b$, orange). For the $0.25-0.28 \mathrm{~m}$ layer, the dominant water regime was $0.40 \mathrm{~m}^{3} \mathrm{~m}^{-3}$ (Figure $3 \mathrm{c}$, green).

Based on these results, it can be inferred that the $0.00-0.03 \mathrm{~m}$ layer was more compressed than the other layers analyzed. According to the manufacturer's manual, the wheeled tractor Massey Ferguson Model 275 applies a maximum static pressure of $240 \mathrm{kPa}$ and the harvester jet KTR applies a maximum static pressure of $276 \mathrm{kPa}$. Taking cognisance of these values and the precompression stress as a function of water content obtained by Kamimura et al. (2012) for the studied plantation, both the tractor and the harvester should not traffic in the farm under these conditions. In this study, the maximum precompression stress of the field at $0.45 \mathrm{~m}^{3} \mathrm{~m}^{-3}$, was $200 \mathrm{kPa}$, which was smaller than the pressured applied by the machines.
If this condition is not respected, then additional compression may occur. The tractor traffic must be wait for a period when the water content reaches a value less than $0.36 \mathrm{~m}^{3} \mathrm{~m}^{-3}$, whereas the use of the combine must wait for the water content to achieve a value less than $0.30 \mathrm{~m}^{3} \mathrm{~m}^{-3}$.

Similarly, the critical volumetric moisture content values for tractor and harvester traffic, as determined by Kamimura et al. (2012), were 0.36 and $0.30 \mathrm{~m}^{3} \mathrm{~m}^{-3}$. Thus, to avoid compacting the soil, the tractor and harvester traffic, must be carried out at water content $\leq 0.36 \mathrm{~m}^{3} \mathrm{~m}^{-3}$ and $\leq 0.30 \mathrm{~m}^{3} \mathrm{~m}^{-3}$, respectively. Another alternative would be to reduce the contact pressure by decreasing the weight on the shaft or increasing the ground-contact area (RAPER, 2005). The increase of contact area, in turn, may be obtained by the use of larger or wider tires and belts or those with a larger diameter, a greater number of wheels per axle, or increased flexibility of the tire housing (MION et al., 2016). Radial tires are more flexible than diagonal; thus, resulting in a larger contact area with the ground (RAPER, 2005). 




Figure 2a. Map of $\sigma p$ in the $0.00-0.03$ m layer

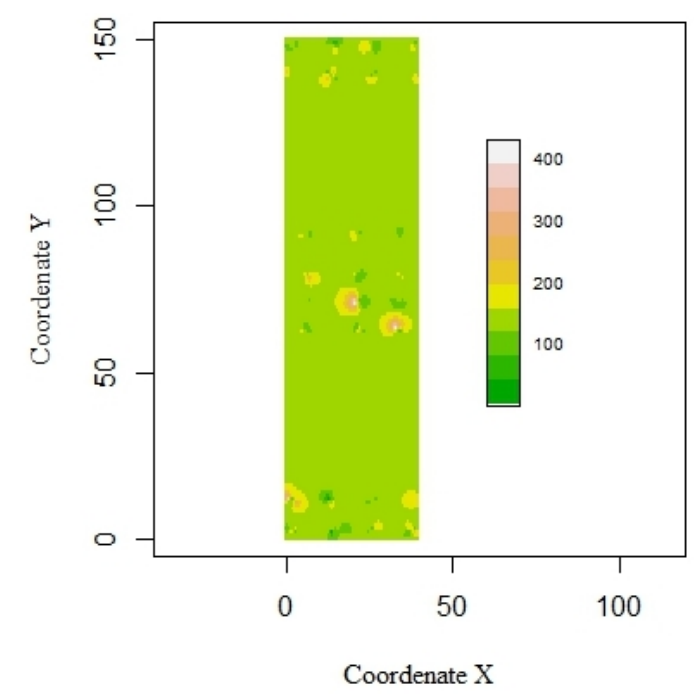

Figure 2b. Map of op in the $0.10-0.13 \mathrm{~m}$ layer



Figure 2c. Map of $\sigma p$ in the $0.25-0.28 \mathrm{~m}$ layer

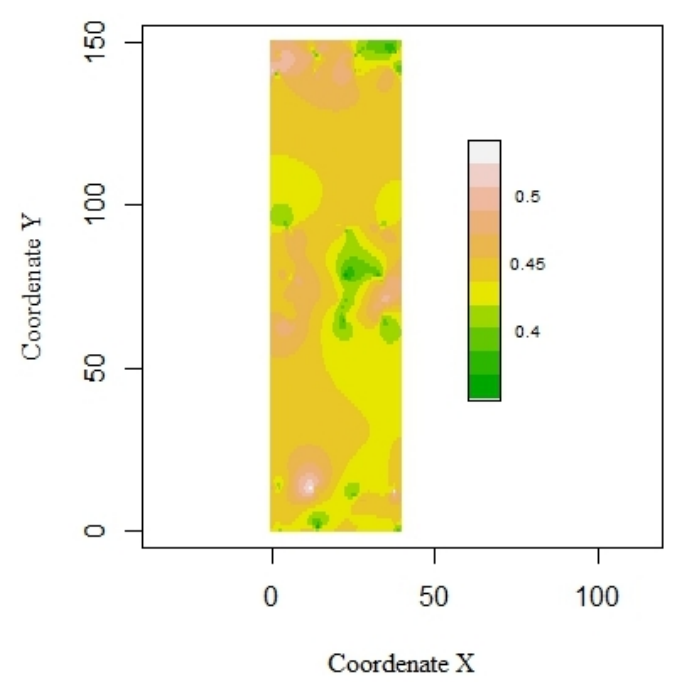

Figure 3a. Map of $\theta$ in the $0.00-0.03 \mathrm{~m}$ layer

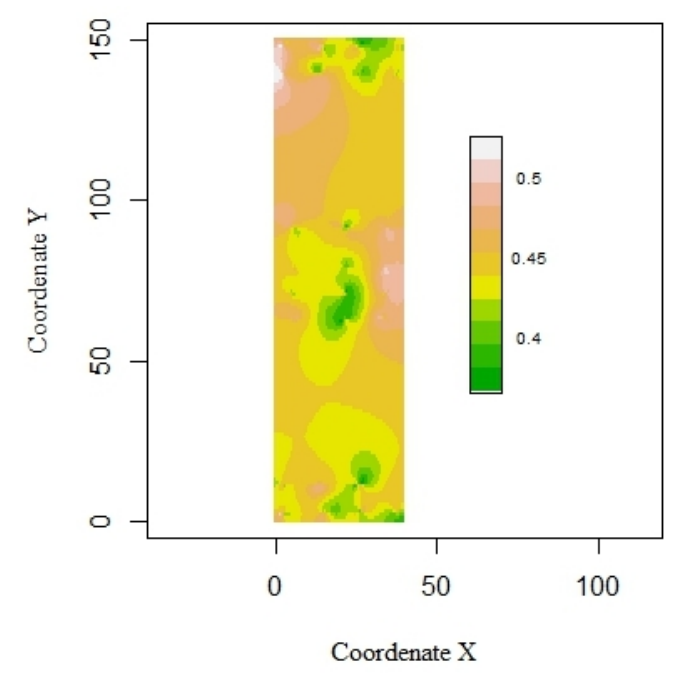

Figure 3b. Map of $\theta$ in the $0.10-0.13 \mathrm{~m}$ layer

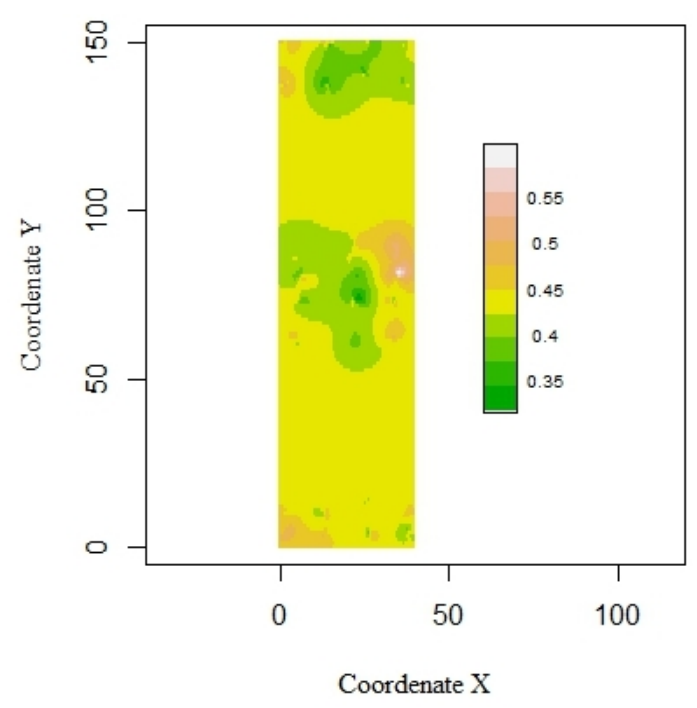

Figure 3c. Map of $\theta$ in the $0.25-0.28 \mathrm{~m}$ layer 


\section{CONCLUSIONS}

The precompression stress and volumetric soil moisture presented a spatially dependent structure and the ordinary kriging technique has been proven to be a viable tool for the estimation of data points not sampled in the experimental area.

The $0-0.03 \mathrm{~m}$ layer presented the highest $\mathrm{LBC}$, indicating that this layer was more compact compared to the other layers.

Based on the precompression stress maps, the Massey Ferguson tractor 275 and Jacto KTR Advance combine must not travel in the area when the water content is equal to $0.45 \mathrm{~m}^{3} \mathrm{~m}^{-3}$ because the
KAMIMURA, K. M. et al.

soil has a load-bearing capacity $200 \mathrm{kPa}$ in this condition.

\section{ACKNOWLEDGMENT}

The authors are thankful for the financial support of CAPES / Proex / AuxPe 593/2018, Brazilian Research and Development Consortium Coffee CBP \& D / Café for the development of this study. The authors also thank the staff of the Experimental Farm in EPAMIG Sponsorship-MG. The first author is grateful to CAPES for granting the doctoral fellowship.

RESUMO: O tráfego intenso de máquinas agrícolas sobre solos cultivados com cafeeiro pode causar alterações significativas na estrutura do solo. Os objetivos deste estudo foram: a) avaliar e identificar a variabilidade espacial da pressão de preconsolidação $(\sigma p)$ e a umidade volumétrica $(\theta)$ de um Latossolo Vermelho-Amarelo (LVA) e determinar a estrutura de dependência espacial através de semivariogramas utilizando a krigagem ordinária; b) verificar no mapa, a profundidade com maior capacidade de suporte de carga (CSC) do solo ; c) dar suporte a tomada de decisão no manejo do maquinário agrícola da cultura cafeeira e utilizar esses mapas para a logística de manejo de trafego de máquinas. $\mathrm{O}$ experimento foi conduzido num LVA textura muito argilosa na Fazenda da Epamig (Empresa de Pesquisa Agropecuária de Minas Gerais), em Patrocínio-MG. A amostragem foi realizada numa malha retangular $(150 \mathrm{~m} \times 40 \mathrm{~m})$, onde foram coletadas amostras indeformadas em anéis metálicos de $0,0254 \mathrm{~m}$ de altura por $0,0630 \mathrm{~m}$ de diâmetro com auxílio do amostrador tipo Uhland em 28 trincheiras. Cada trincheira possui três degraus que correspondem às profundidades de $(0.00-0.03 ; 0.10-0.13$ e $0.25-0.28 \mathrm{~m})$ e as dimensões dos degraus foram de $2,0 \times 1,5 \mathrm{~m}$, coletaram-se sete amostras (disposta em forma matricial) para cada degrau, totalizando 588 amostras. A $\sigma p$ e $\theta$ apresentaram estrutura de dependência espacial. A profundidade de $0.00-0.03 \mathrm{~m}$ apresentou maior CSC indicando que esta profundidade está mais compactada em relação as demais profundidades. Com base nos mapas da $\sigma \mathrm{p}$, o trator e a colhedora não devem trafegar na área para umidade volumétrica igual a $0.45 \mathrm{~m}^{3} \mathrm{~m}^{-3}$, pois o solo possui CSC de $200 \mathrm{kPa}$. Se essa condição for desrespeitada, a compactação adicional poderá ocorrer. Para o tráfego do trator, deve-se esperar por um período, para que a $\theta$ atinja um valor menor que 0.36 $\mathrm{m}^{3} \mathrm{~m}^{-3}$, enquanto que para o tráfego da colhedora deve-se esperar a $\theta$ atingir valor menor que $0.30 \mathrm{~m}^{3} \mathrm{~m}^{-3}$.

PALAVRAS-CHAVE: Compactação. Geoestatística. Capacidade de suporte de carga.

\section{REFERENCES}

AJAYI, A. E.; DIAS JUNIOR, M. S.; CURI, N.; ARAUJO JUNIOR, C. F.; SOUZA, T. T. T.; INDA JUNIOR, A. V. Strength attributes and compaction susceptibility of Brazilian Latosols. Soil and Tillage Research, Amsterdam, v.105, n.1, p.122-127, 2009. https://doi.org/10.1016/j.still.2009.06.004

ARAÚJO JÚNIOR, C.F.; DIAS JÚNIOR, M.S.; GUIMARÃES, P.T.G.; ALCÂNTARA, E.N. Capacidade de suporte de carga e umidade crítica de um Latossolo induzida por diferentes manejos. Revista Brasileira de Ciência do Solo, v.35, n.1, p.115-131, 2011. https://dx.doi.org/10.1590/S0100-06832011000100011

CAMBARDELLA, C. A.; MOORMAN, T. B.; NOVAK, J. M.; PARKIN, T. B.; KARLEN, D. L.; TURCO, R. F. \& KONOPKA, A. E. Field-scale variability of soil properties in central Iowa soils. Soil Science Society of America Journal, v.58, n.5, p.1501-1511, 1994. https://doi:10.2136/sssaj1994.03615995005800050033x 
DIAS JÚNIOR, M. S.; PIERCE, F. J. A simple procedure for estimating preconsolidation pressure from soil compression curves. Soil Technology, v.8, n.2, p. 139-151, 1995. https://doi.org/10.1016/0933-3630(95)000158

DIGGLE, P. J.; RIBEIRO JÚNIOR, P. J. Model based geostatistics. In: SIMPÓSIO NACIONAL DE PROBABILIDADE E ESTATÍSTICA, 14., Caxambu, 2000. Resumos.Caxambu: Associação Brasileira de Estatística, 2000. p.192.

DONAGEMA, G. K.; CAMPOS, D. V. B.; CALDERANO, S. B.; TEIXEIRA, W. G., \& VIANA J. H. M. Manual de métodos de análise de solo. Rio de Janeiro: Embrapa Solos, 2017, 514p.

EMPRESA BRASILEIRADE PESQUISA AGROPECUARIA - EMBRAPA. Centro Nacional de Pesquisas de Solos. Sistema brasileiro de classificação de solos. 5. ed. Brasília, DF, Embrapa Solos, 2018. 356 p.

FERREIRA, D. F. Estatística básica. 2. ed. Lavras, UFLA, 2009. 664 p.

FERREIRA, D. F. Sisvar: a computer statistical analysis system. Ciência e Agrotecnologia (UFLA), v. 35, n.6, p. 1039-1042, 2011. https://doi.org/10.1590/S1413-70542011000600001

GONTIJO, I.; DIAS JUNIOR, M. S.; OLIVEIRA, M. S.; ARAUJO-JUNIOR, C. F.; PIRES, B. S. \& OLIVEIRA, C. A. Planejamento Amostral da Pressão de Preconsolidação de um Latossolo Vermelho Distroférrico. Revista Brasileira de Ciência do Solo, v.31, n.6, p.1245-1254, 2007.

http://dx.doi.org/10.1590/S0100-06832007000600003

GONTIJO, I.; DIAS JUNIOR, M. S.; GUIMARÃES, P. T. G.; OLIVEIRA, M. S. \& AJAYI, A. E. Spatial patterns of preconsolidation pressure and soil moisture along transects in two directions under coffee. Revista Brasileira de Ciência do Solo, v.35, n.4, p.1189-96, 2011. http://dx.doi.org/10.1590/S010006832011000400012

HORN, R.; FLEIGE, H. A method for assessing the impact of load on mechanical stability and on physical properties of soils. Soil Tillage Research v.73, p.89-99, 2003. https://doi.org/10.1016/S0167-1987(03)00102-8

JOURNEL, A. G.; HUIJBREGTS, C. H. J. Mining Geostatistics. Academic Press, London, p. 600, 1978.

KAMIMURA, K. M.; DIAS JÚNIOR, M. S.; GUIMARÃES, P. T. G., SANTOS, G. R. \& OLIVEIRA, M. S. Capacidade de suporte de carga de um Latossolo Vermelho-Amarelo em uma lavoura cafeeira. Revista Brasileira de Ciência do Solo, v.36, n.5, p.1457-1465, 2012. http://dx.doi.org/10.1590/S010006832012000500009

KONDO, M. K. Variabilidade espacial do comportamento compressivo do solo e mapas de trafegabilidade na cultura do cafeeiro irrigado. Tese (Doutorado em Solos e Nutrição de Plantas) Faculdade de Agronomia, p.166, Lavras, Universidade Federal de Lavras, 2003.

MATHERON, G. The theory of regionalized variables and its application. Paris: Les Cahiers du centre de Morphologie Mathematique, Fas. 5, C.G. Fontainebleau, 1971, p.211.

MION, R. L.; HOLANDA, A. S.; BARROSO, S. H. \& SILVA, S. A. T. E. Tensões aplicadas no solo pelas diferentes pressões do pneu de um trator agrícola. Engenharia Agrícola, Jaboticabal, v. 36, n.1, p.63-77. 2016. http://dx.doi.org/10.1590/1809-4430-Eng.Agric.v36n1p63-77/2016

NEIVA JÚNIOR, E.; ROCHA, W. W.; PIRES, B. S.: FARNEZI, M. M. M., DIAS JUNIOR, M. S.; FREITAS, D. F. B.; SILVA, E. B. \& CARVALHO, G. A. O. Compressibility and penetrability of Latossolo VermelhoAmarelo distrófico (oxisol) under varied management systems and land uses. Revista Brasileira de Ciência do Solo, v.39, n.1, p.86-93, 2015. https://dx.doi.org/10.1590/01000683rbcs20150032 
RAPER, R. L. Agricultural traffic impacts on soil. Journal of Terramechanics, v.42, p.259-280, 2005. https://doi.org/10.1016/j.jterra.2004.10.010

RIBEIRO, J. R.; DIGGLE, P. P. GeoR: a package for Geostatistical analysis. R- N., Rochester, 1: 15-18, 2001.

SEIDEL, E. J. \& OLIVEIRA, M. S. A classification for a geostatistical index of spatial dependence. Revista Brasileira de Ciência do Solo, Viçosa, v.40, p.e0160007. http://dx.doi.org/10.1590/18069657rbcs20160007

SILVA, E. M.; MALVINO, S. S. A. B. Análise climática do município de Patrocínio (MG). Caminhos da Geografia, v.10, p.93-108, 2005.

SILVA, R. B. D.; IORI, P.; SOUZA, Z. M. D.; PEREIRA, D. D. M. G.; VISCHI FILHO, O. J. \& SILVA, F.A.D.M. Contact pressures and the impact of farm equipment on Latosol with the presence and absence of sugarcane straw. Ciência e Agrotecnologia, v.40, n.3, p.265-278, 2016. http://dx.doi.org/10.1590/141370542016403001716

TAYLOR, D. W. Fundamentals of soil mechanics. New York: John Wiley, 1948, p.770. https://doi.org/10.1097/00010694-194808000-00008

VIEIRA, S. R.; GUEDES FILHO, O.; CHIBA, M. K.; CANTARELLA, H. Spatial variability of soil chemical properties after coffee tree removal. Revista Brasileira de Ciência do Solo. v.33, n.5, p.1507-1514, 2009. http://dx.doi.org/10.1590/S0100-06832009000500041

VIEIRA, S. R.; CARVALHO, J. R. P.; GONZALEZ, A. P. Jack knifing for semivariogram validation. Bragantia. v.69, suplemento 0, p.97-105, 2010. http://dx.doi.org/10.1590/S0006-87052010000500011

WARRICK, A. W.; NIELSEN, D. R. Spatial variability of soil physical properties in the field. In: HILLEL, D. ed. Applications of soil physics. New York, Academic Press, 1980, 319-344p. https://doi.org/10.1016/B978-0$12-348580-9.50018-3$

YAMAMOTO, J. K.; LANDIM, P. M. B. Geoestatística: conceitos e aplicações. 1. ed. São Paulo: Editora Oficina de Textos, v.1, 2013, 215p. 